\title{
THE IMPROVEMENT OF COGNITIVE DEFICITS AFTER WHOLE-BODY CRYOTHERAPY - A RANDOMISED CONTROLLED TRIAL
}

Joanna Rymaszewska ${ }^{1}$, Katarzyna M. Lion ${ }^{1,2 *}$, Bartłomiej Stańczykiewicz ${ }^{3}$, Julia E. Rymaszewska $^{4}$, Elżbieta Trypka ${ }^{1}$, Lilla Pawlik-Sobecka ${ }^{3}$, Izabela Kokot ${ }^{5}$, Sylwia Płaczkowska ${ }^{6}$, Agnieszka Zabłocka ${ }^{7}$ and Dorota Szcześniak ${ }^{1}$

${ }^{1}$ Wroclaw Medical University, Department of Psychiatry, Wroclaw, Poland

${ }^{2}$ Menzies Health Institute Queensland, Griffith University, Australia

${ }^{3}$ Department of Nervous System Diseases, Wroclaw Medical University, Poland

${ }^{4}$ Student Scientific Association at Department of Psychiatry, Wroclaw Medical University, Poland

${ }^{5}$ Department of Laboratory Diagnostics, Division of Laboratory Diagnostics, Faculty of Pharmacy, Wroclaw Medical University, Wroclaw, Poland

${ }^{6}$ Department of Laboratory Diagnostics, Diagnostics Laboratory for Teaching and Research, Faculty of Pharmacy, Wroclaw Medical University, Wroclaw, Poland

${ }^{7}$ Laboratory of Microbiome Immunobiology, Hirszfeld Institute of Immunology and Experimental Therapy, Polish Academy of Sciences, Wroclaw, Poland

*Correspondence author

Address: Wroclaw Medical University, Department of Psychiatry, Pasteura 10, 50-367

Wroclaw, Poland; e-mail: k.lion@ griffith.edu.au 


\section{ABSTRACT}

Background: Whole-Body Cryotherapy (WBC) - a repetitive, short-term exposure to extremely low temperatures - may become an effective early intervention for mild cognitive impairment (MCI). It is a heterogeneous group of symptoms associated with cognitive dysfunction which is estimated to transform into dementia in $50 \%$ cases.

Study design: The prospective randomised double-blind sham-controlled study aimed to determine the efficacy of WBC on cognitive functioning and biological mechanisms. The study was registered with Australian New Zealand Clinical Trials Registry (ACTRN12619001627145).

Methods: Participants with MCI $(n=62 ;(20<M o C A>26)$ were randomly allocated to cryogenic temperatures $\left(-110^{\circ} \mathrm{C}\right.$ till $\left.-160^{\circ} \mathrm{C}\right)(\mathrm{EG}, \mathrm{n}=33)$ or placebo-controlled group $(\mathrm{CG}, \mathrm{n}=29)$. Cognitive functions were measured at baseline (T1), after the $10^{\text {th }} \mathrm{WBC}$ session (T2) and after 2 week-break (T3) with DemTect, SLUMS and Test Your Memory (TYM). Secondary outcome measures included quality of life (WHOQoL-BREF), self-reported well-being (VAS) and depressive symptoms (GDS). Whole blood samples $(10 \mathrm{ml})$ were collected at $\mathrm{T} 1$ and $\mathrm{T} 2$ to evaluate levels of cytokines, neurotrophins, NO and biochemical parameters CRP total cholesterol, prolactin).

Results: There were significant differences between groups measured at T2 in immediate recall (DemTect) and in orientation (TYM) in favour of WBC group. Improvement in mood was detected in self-reported depressive symptoms level (WHOQoL-26; T2 p=0.04; VAS mood T2 p=0.02; T3 $\mathrm{p}=0.07)$. The significant reduction of BDNF level was observed $(\mathrm{p}<0.05)$.

Conclusions: WBC may increase the performance of cognitive functions. It seems promising to combine WBC with existing behavioural and cognitive trainings in the future studies investigating early interventions methods in MCI.

Keywords: whole-body cryotherapy; mild cognitive impairment; memory improvement; supportive therapy; randomized controlled trial 


\section{HIGHLIGHTS}

- The first RCT on the impact of whole-body cryotherapy on cognitive functions

- WBC may increase the performance of cognitive functions among people with MCI

- WBC may regulate the level of brain derived neurotrophic factor (BDNF) 


\section{Introduction}

Due to an ageing world population, the increased prevalence of neurocognitive disorders will compare to cardiovascular or neoplastic diseases within the next few decades (WHO, 2015). Neurocognitive disorders, like dementia, are of significant interest as there are no treatments that modify disease progression.

Mild cognitive impairment (MCI) includes a heterogeneous group of symptoms associated with cognitive dysfunction, and usually refers to the transition period between normal functioning and dementia. It is estimated that between 41-64\% of people diagnosed with MCI will develop dementia during their lifetime (Gauthier et al., 2006). Due to the progressive and irreversible nature of dementia, novel therapeutic strategies, employed at an early stage of cognitive impairment, are a much needed intervention. One such proposed intervention involves a repetitive, short-term exposure to extremely low temperatures (maximum 3 minutes for adults) termed Whole-Body Cryotherapy (WBC), also known as whole-body cryostimulation. This method is already used as a supplementary therapy in other clinical areas, such as neurology, rheumatology, and sport medicine (Bouzigon et al., 2016). It is also commonly used as a treatment in inflammatory diseases. Induced hypothermia is a similar approach utilised for its neuroprotective effects in acute brain injuries caused by ischemic events. Numerous in vitro and animal model studies have also reported possible protective effects from exposure to extremely low temperature (Bouzigon et al., 2016).

WBC has become a standard form of treatment and rehabilitation in the course of neurological and musculoskeletal disorders in some countries, including Poland. Currently, WBC is most commonly used in the treatment of rheumatology disorders that involve pain, joint swelling, and mobility limitations - mainly in spinal and peripheral joint osteoarthritis as well as in rheumatoid disease (Gizińska et al., 2015; Stanek et al., 2015; Yamauchi, 1986). Indications for WBC also include spastic paresis in the course of multiple sclerosis (Lubkowska, 2013). Its use in fibromyalgia also has beneficial clinical effects and reduces pain (Kanecki and Tyszko, 2016; Rivera et al., 2018; Vitenet et al., 2018). Lately WBC is more and more often used in healthy subjects as a method to promote wellbeing (Stanek et al., 2019, 2016). Preliminary evidence of WBC benefits in the mental health area, including improving quality of life (Szczepańska-Gieracha et al., 2014), reducing depressive symptoms (Rymaszewska et al., 2020, 2019; Rymaszewska and Ramsey, 2008) and improving cognitive functions, as well as biochemical blood parameters, have been reported in people with MCI (Rymaszewska et al., 2018).

The systemic effect of cryogenic temperatures is associated with analgesic, neuro-muscular, antiedematous, anti-inflammatory, hormonal and circulatory reactions (Rymaszewska and Mazurek, 2012). It is hypothesised that WBC may be used in prevention and early intervention of MCI and Alzheimer's Disease (AD) (Misiak and Kiejna, 2012). Studies indicate that low temperatures may have a protective effect on the central nervous system (Dietrich and Bramlett, 2010). This effect is applied in emergency medicine with induced hypothermia to treat acute vascular conditions, such as 
strokes (Lubkowska, 2013). Immunomodulation is another potential effect of WBC. Researchers have found that exposure to extremely low temperatures leads to a decrease in oxidative stress and proinflammatory cytokines (IL-1, IL-2, TNF- $\alpha$ ) and an increase in the concentration of anti-inflammatory cytokines (IL-6, IL-10) (Banfi et al., 2009; Stanek et al., 2018). Markers of inflammatory response, such as C Reactive Protein (CRP) and sICAM-1 were also downregulated, which is of importance in patients with dementia due to the correlation of cognitive impairment with neuroinflammation (Bouzigon et al., 2016; Kim et al., 2012). The synaptic dysfunction and apoptosis of neuronal cells observed in Alzheimer's disease is caused by chronic neuroinflammation induced in response to an accumulation of highly insoluble amyloid beta peptide deposits. A continuous pro-inflammatory reaction includes a decrease in microglia activity, and the altered secretion of reactive oxygen species, nitric oxide (NO), chemokines, and cytokines, and inflicts damage to the blood-brain barrier (Brosseron et al., 2014; Faria et al., 2014; Janoutová et al., 2015; Magaki et al., 2007; Saleem et al., 2015).

It has been reported that inflammatory markers, or markers of an impaired immune response, can be used to monitor Alzheimer's disease progression (McGeer and McGeer, 1998; Richartz et al., 2005). An altered immune profile has also been found in MCI patients. In MCI, and AD patients who had progressed from MCI, a higher levels of pro-inflammatory cytokines (e.g. TNF- $\alpha$, IL-1 $\beta$ or IL-6) in serum/plasma was observed when compared to healthy controls (Su et al., 2016; Wang et al., 2015). A reduction in levels of anti-inflammatory factors like IL-10 or TGF- $\beta$ was also observed (Tarkowski et al., 2003; Wang et al., 2015). Oxidative stress has been also recognized as a contributing factor in ageing, $\mathrm{AD}$, and the progression of multiple neurodegenerative diseases (Massaccesi et al., 2019; Tönnies and Trushina, 2017). Alterations in the immune response in MCI would suggest that inflammatory events may precede the clinical development of AD.

There is a significant amount of studies supporting the idea that neurotrophic factors are crucial for the etiology of AD, in particular BDNF (Brain Derived Neurotrophic Factor) (Miranda et al., 2019). BDNF, a member of the nerve growth factor family, plays an important role in neuronal survival, differentiation, and synaptic plasticity in the CNS, particularly in brain regions susceptible to degeneration in AD (Angelucci, 2009; Faria et al., 2014; Miranda et al., 2019). Several studies have revealed an alteration in BDNF expression in the post-mortem brains of AD patients, however, with contrasting results. Some studies showed a decrease of BDNF mRNA and protein level in both preclinical (Holsinger et al., 2000) and end-stage AD brain (Savaskan et al., 2000). This reduction was also reported in MCI (Shimada et al., 2014). There is also some experimental evidence that peripheral BDNF level is significantly higher in MCI patients and AD patients, when compared to the healthy controls (Angelucci, 2009; Faria et al., 2014; Kim et al., 2017; Miranda et al., 2019).

This research project aimed to determine the efficacy of Whole-Body Cryotherapy on cognitive functioning and its biological mechanisms in people with mild cognitive impairment (MCI). 
2. Materials and methods

\subsection{Study design}

This study was conducted as a prospective randomized double-blind sham-controlled trial with the research protocol reviewed and approved by the Bioethical Committee of the Wroclaw Medical University (permission numbers: KB-665/2014, KB-124/2015). The research protocol was performed in compliance with the Declaration of Helsinki. The study was retrospectively registered with Australian New Zealand Clinical Trials Registry (ACTRN12619001627145). All participants received oral and written information about the study design, anonymity, and informed they could withdraw from the study at any time and provided written consent. Figure 1 presents the study design.

\subsection{Procedure}

Participants from the experimental group undertook 10 WBC sessions for two weeks (1 per day from Monday - Friday, no sessions were conducted on the weekend). Cryochamber CR 2002 (Wroclaw type, provided by Creator Sp. z o. o.) was used in this study. The cryochamber consists of two rooms; the vestibule/antechamber (temperature $-60^{\circ} \mathrm{C}$ ); and the main chamber (temperature $-110^{\circ} \mathrm{C}$ at the first day till $-135^{\circ} \mathrm{C}$ further on). The device was cooled by liquid nitrogen (with no direct contact with the liquid nitrogen). The WBC session lasts for 2 minutes in the main chamber. Each session in the main chamber is preceded and followed by a 30 second adaptation session in the vestibule/antechamber. Blood pressure was measured prior to each session, and all sessions were supervised by medical personnel. Groups of 5-6 participants used the WBC chamber at the same time.

29 Participants in the control (sham) group undertook 10 sessions for two weeks (1 per day from Monday - Friday, no sessions were conducted on the weekend) in the vestibule/antechamber (temperature $-50^{\circ} \mathrm{C}$ ). Because of the technical elements of maintaining higher temperatures in the cryochamber, participants from the control (sham) group entered the cryochamber in the opposite way, through the main chamber $\left(-20^{\circ} \mathrm{C}\right)$ to the vestibule with lower temperature $\left(-50^{\circ} \mathrm{C}\right)$ for 2 minutes.

All other aspects of the control procedure were performed exactly as for the experiment intervention. Both experimental and control sessions were performed between 5:00 PM and 7:00 PM. All participants (from both experimental and control group) were required to wear minimal woollen or cotton clothing (i.e. shorts and t-shirt), gloves, headband (or beanie), a nose and mouth mask, highknee socks and dry shoes (i.e. wooden) during the WBC. Regardless of group, each session was conducted similarly.

There were 3 assessments during the study. Before the first WBC session (T1), after the last $\left(10^{\text {th }}\right)$ WBC (T2), and finally two weeks later at follow-up (T3). Blood was collected from all participants at T1 and T2. The blood specimens were collected before the first session on Monday (approximately half an hour before WBC session) and immediately after the last session on Friday. The detailed 
structure of the procedure is presented on the Figure 1. There were no additional changes in the study protocol after commencement. The study took place between January 2015 and December 2018.

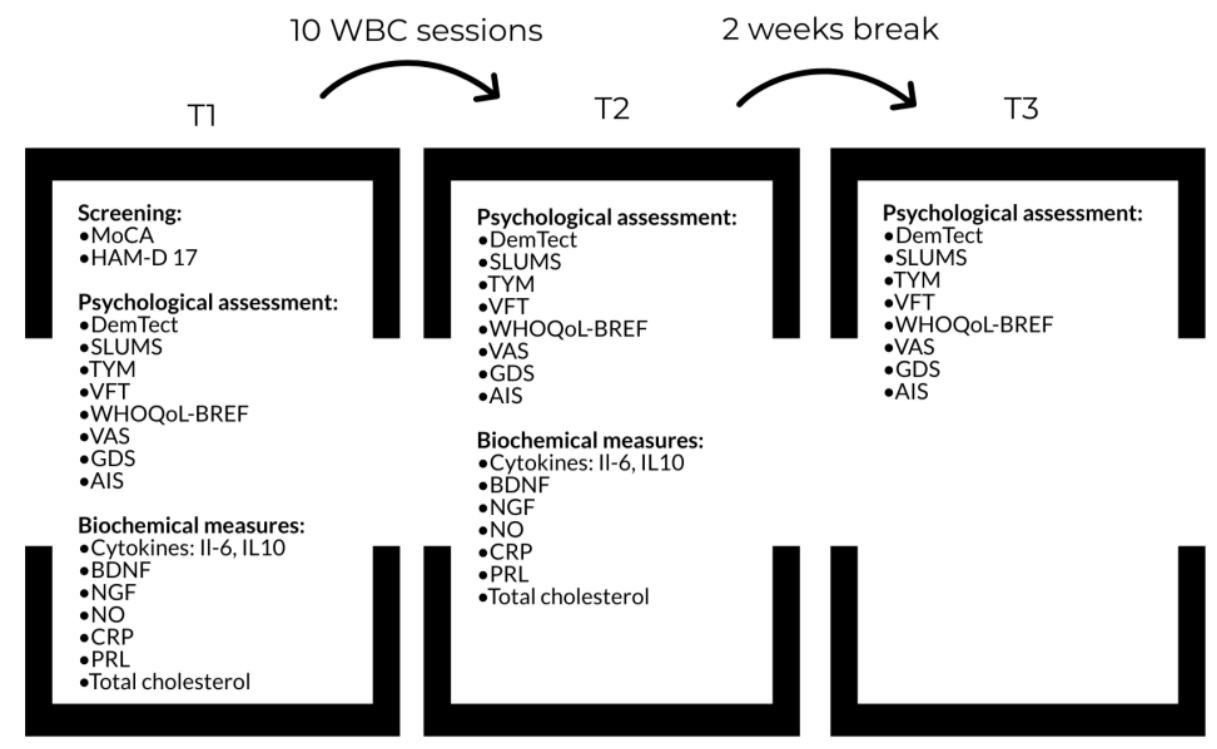

Figure 1. Study design

MoCA - Montreal Cognitive Assessment; HAM-D 17 - Hamilton Depression Rating Scale; SLUMS - Saint Louis University Mental Status Examination; TYM - Test Your Memory; VFT - Verbal Fluency Test; WHOQoL-BREF - World Health Organization Quality of Life BREF; VAS - Visual Analogue Scale; GDS - Geriatric Depression Scale; AIS - Acceptance of Illness Scale; BDNF - Brain Derived Neurotrophic Factor; NGF - nerve growth factor; NO - nitric oxide; CRP - C- Reactive Protein; PRL - Prolactin; WBC sessions (10 WBC sessions or 10 control sessions)

\subsection{Randomisation}

The participants were randomly allocated via randomisation software to be exposed to cryogenic temperature ranging from $-110^{\circ} \mathrm{C}$ to $-135^{\circ} \mathrm{C}$ (the experimental group, EG) or to low, but not cryogenic, temperatures $-50^{\circ} \mathrm{C}$ (the control group, CG). People were assigned to the groups by the research assistant not involved in assessment procedures. Both investigators and subjects remained blind. Participants did not receive information about being allocated to the experimental or control group, a temperature display on the cryochamber was covered for both groups at each session. Researchers involved in the assessment pre-, during, and post- intervention were not informed about the randomisation outcomes. Only the research assistant, responsible for the randomisation, and a person responsible for the cryochamber preparation were not blinded.

\subsection{Study participants}

112 people with mild cognitive impairment $(\mathrm{MCI})$ were recruited from the outpatients' clinic in Wroclaw Medical University Hospital, via local media adverts as well as through word-of-mouth. The study enrolled 86 medically stable (based on physical examination, medical history and vital signs at screening) adults (aged 49-80 years) with a diagnosis of mild cognitive impairment (MCI; F06.7 according to research criteria of International Classification of Diseases, ICD-10) (World Health Organization, 2004) with additional inclusion criteria based on the Montreal Cognitive Assessment (MoCA) test (Magierska et al., 2012; Nasreddine et al., 2005; Talarowska et al., 2011) (scores 
between 20 and 26). The exclusion criteria included 1) a lack of or more advanced cognitive decline $(20<\mathrm{MoCA}>26), 2)$ depression, 3) previous exposure to WBC 4) being over 80 years old and 5) all standard contraindications to use WBC (e.g. alcohol and drug abuse, inability to understand questions and written information, psychosis, suicidal thoughts, standard contraindications to use WBC (e.g. acute respiratory diseases, acute cardiovascular disease like coronary disease, circulatory insufficiency, unstable hypertension, cold intolerance, claustrophobia, cryoglobulinemia, cancer, deep vein diseases, hypothyroidism, neuropathies, purulent skin changes, Reynaud disease).

86 participants who met the inclusion criteria were randomised into experimental (EG) or shamcontrol group (CG) from whom 33 people completed $10 \mathrm{WBC}$ sessions in EG and 29 in CG. Before starting the WBC sessions 8 (4 in CG and 4 in EG) people dropped-out from the study (because of undiagnosed high blood pressure - those were referred to their GPs; fear of WBC; developing cold/flu, other life events). 33 participants in the EG completed 10 WBC cryotherapy sessions and took part in T2 assessment; 29 people completed all 10 sham sessions in CG. Additionally, 1 person from EG and 5 from CG refused to participate in the T3 assessment (two weeks after the last WBC session). The detailed flow diagram, including drop-out reasons is presented in Figure 2.

[Figure 2. Flow Diagram] 


\section{CONSORT \\ TRANSPARENT REPORTING Of TRIALS}

CONSORT 2010 Flow Diagram



Finally, 62 people enrolled in the study completed all 10x WBC sessions -33 in experimental and 29 in control group. Mean age for EG was 65.97( \pm 6.94$)$ and $67.45( \pm 5.72)$ for CG group. Majority of participants were female (69.7\% in EG and $56.6 \%$ in CG). Over $80 \%$ of participants in both groups completed higher education (27.3\% EG and 34.5\% CG) or secondary education (57.6\% EG and 51.7\% CG). The level of depressive symptoms was assessed at the baseline with 2.15( \pm 2.83$)$ mean score in HAMD-17 for EG and 3.03( \pm 5.38$)$ for $\mathrm{CG}(\mathrm{p}=0.95)$. There were no significant demographic differences between participants randomised into EG and CG, or clinical background characteristic differences $(\mathrm{p}>0.05)$. The detailed demographical characteristics are presented in Table 1.

Table 1 Participant demographics (n=62).

\begin{tabular}{llcccccc}
\hline Variable & & \multicolumn{2}{c}{ Experimental Group (EG) } & \multicolumn{2}{c}{ Control Group (CG) } & p- \\
\cline { 2 - 6 } value \\
Gender & Female & $\mathbf{N}=\mathbf{3 3}$ & $\mathbf{\%}$ & $\mathbf{N = 2 9}$ & $\mathbf{\%}$ & $56.6 \%$ & 0.43
\end{tabular}




\begin{tabular}{|c|c|c|c|c|c|c|}
\hline \multirow{5}{*}{ Education } & Male & 10 & $30.3 \%$ & 12 & $41.4 \%$ & \multirow{5}{*}{0.64} \\
\hline & $\begin{array}{l}\text { Primary } \\
\text { education }\end{array}$ & 2 & $6.0 \%$ & - & - & \\
\hline & Vocational & 3 & $9.1 \%$ & 4 & $13.8 \%$ & \\
\hline & $\begin{array}{l}\text { education } \\
\text { Secondary } \\
\text { education }\end{array}$ & 19 & $57.6 \%$ & 15 & $51.7 \%$ & \\
\hline & $\begin{array}{l}\text { Higher } \\
\text { education }\end{array}$ & 9 & $27.3 \%$ & 10 & $34.5 \%$ & \\
\hline & & Mean $( \pm$ SD $)$ & $\begin{array}{c}\operatorname{Median}\left(\mathbf{Q}_{1^{-}}\right. \\
\left.\mathbf{Q}_{3}\right)\end{array}$ & Mean $( \pm$ SD $)$ & $\begin{array}{c}\operatorname{Median}\left(\mathbf{Q}_{1^{-}}\right. \\
\left.\mathbf{Q}_{3}\right)\end{array}$ & $\begin{array}{c}\text { p- } \\
\text { value }\end{array}$ \\
\hline \multirow{3}{*}{$\begin{array}{l}\text { Age } \\
\text { MoCA } \\
\text { HAMD- } \\
17\end{array}$} & & $65.97( \pm 6.94)$ & $65(62-69)$ & $67.45( \pm 5.72)$ & 68(64-70) & 0.33 \\
\hline & & $23.76( \pm 1.7)$ & $24(22-25)$ & $23.83( \pm 1.77)$ & $24(23-25)$ & 0.89 \\
\hline & & $2.15( \pm 2.83)$ & $0(0-4)$ & $3.03( \pm 5.38)$ & $1(0-3)$ & 0.95 \\
\hline
\end{tabular}

$* \mathrm{p} \leq 0.05$

\subsection{Instruments}

\subsubsection{Primary outcome measures}

The primary outcome measures were cognitive functions measure at baseline (T1) and after the $10^{\text {th }}$ WBC session (T2) by DemTect ${ }^{\circledR}$ and Saint Louis University Mental Status Examination (SLUMS).

DemTect ${ }^{\circledR}$ is a relatively short (takes around 10-12 minutes to complete) screening test for MCI and early stages of dementia and is a validated tool to monitor the changes in cognition. It is especially sensitive to memory deficits. The whole test consists of 5 subscales: (1) a word list, (2) number transcoding, (3) supermarket (semantic fluency), (4) digit span reverse and (5) word list delayed recall (Fischer-Altevogt et al., 2002). This tool was validated for the Polish population (Wojtyńska and Szcześniak, 2016).

Saint Louis University Mental Status Examination (SLUMS) (Tariq et al., 2006) consists of 11 cognitive tasks with total score of 30 points, which takes up to 10 minutes. It assesses allopsychic orientation, delayed memory, arithmetic skills, abstract thinking, ability to concentrate, categorial fluency, executive functions and logical memory. The test was translated and validated for Polish population (Szcześniak and Rymaszewska, 2015).

\subsubsection{Secondary outcome measures}

Test Your Memory (TYM) is also a screening tool for assessing cognitive functions. It was developed by Brown et al. (2009) in the UK. Comparing to the majority of cognitive screening tools TYM differs from standard tests - it is filled out by the patient. It analyses 10 cognitive areas: orientation, the ability to copy a sentence, semantic knowledge, calculation, verbal fluency, abstract thinking, naming, visuospatial abilities, recall of a copied sentence, and the assessment of one's independence. A version of TYM developed and validated at Wroclaw Medical University, Poland was used in this study (Szczesniak et al., 2013). 
Verbal Fluency Test (VFT) was applied to assess executive functions and semantic memory. Participants were asked to articulate as many words belonging to a certain category or starting from a given letter as possible in a certain time period (usually 60s). For this study, phonetic fluency (letters: F, A and S) was assessed (Ponichtera-Kasprzykowska and Sobów, 2015) at T1, T2 and T3.

The World Health Organization Quality of Life - BREF (WHOQoL - BREF) (WHOQOL-BREF WHO, 1996) was created based on WHOQoL-100 by World Health Organisation Group as the universal tool to assess the quality of life. It is commonly used among healthy people as well as patients diagnosed with different diseases, both for clinical and scientific purposes. It consists of 26 questions. Two questions are about individual, general quality of life and health. 24 items are gathered into 4 domains: physical (D1), psychological (D2), social (D3) and environmental (D4). All questions are scored between 1 and 5. Higher summary score indicates better life quality. WHOQoL-BREF was adapted into polish by Wołowicka and Jaracz (Jaracz et al., 2006).

Visual Analogue Scales (VAS) were used to record self-report on "well-being" issues including: mood (VAS 1), vitality (VAS 2) and sleep quality (VAS 3). Participants were asked to cross the vertical line $(10 \mathrm{~cm})$ between two extreme points $(0$ - the worse mood and 10 - the best mood).

Acceptance of Illness Scale (AIS) was used to measure the level of acceptance of the disease (depression). This tool is highly recommended for use in clinical trials )(Juczyński, 2001; Mazurek and Lurbiecki, 2014).

The 15-item Geriatric Depression Scale (GDS) was used to control the depressive symptoms among participants at T1, T2 and T3 (Albiński et al., 2011; Yesavage et al., 1983).

The Hamilton Depression Rating Scale (HAM-D 17) was used at T1 by psychiatrist to exclude people with depressive disorder. This tool is widely used to measure depressive symptoms. Each symptom can be scored between 0 and 4 . The total score 7-12 points is considered to be mild depressive disorder, 13-17 - moderate, 18-29 - severe and 30-52 very severe (Hamilton, 1960).

Additionally, safety measures included adverse events reported at each visit. A physical examination (including blood pressure, heart rate) was performed at each WBC session.

\subsubsection{Biochemical measurements}

Venous blood samples $(10 \mathrm{ml})$ were collected before the first session $(\mathrm{T} 1)$, and after the $10^{\text {th }} \mathrm{WBC}$ session (T2). Blood samples were obtained using the S-Monovette system (Sarstedt, Nümbrecht, Germany). One tube with an appropriate amount of sodium heparin anticoagulant to obtain blood plasma, and the second $(5 \mathrm{ml})$ containing a clotting activator in order to obtain blood serum. Both tubes were centrifuged in standard conditions, with either plasma or serum obtained. In blood serum, CRP (C-reactive protein) was determined by the CRP High Sensitivity kit (DiaSys, Germany), and total cholesterol (DiaSys, Germany) using Konelab 20i (ThermoScientific) biochemical analyzer. The concentration of prolactin (PRL) levels was measured using techniques ELFA (Enzyme Linked Fluorescent testing) in the mini- Vidas analyzer (Biomerieux SA France). 
The level of cytokines (IL-6, IL-10) and neurotrophins (BDNF- Brain Derived Neurotrophic Factor; NGF - Nerve growth factor) were determined in blood plasma using commercially available ELISA kits (BioLegend, San Diego, CA; and R\&D System, Minneapolis, MN, respectively), according to the procedure recommended by the manufacturer. NO level was determined by the Griess method. The absorbance was measured using spectrophotometry (Enspire 2300 Multilabel Rider, Perkin Elmer).

\subsection{Statistical analysis}

Difference between experimental and control group in T1 was tested using Mann-Whitney test (for continuous variables) or Fisher's exact test (for nominal and ordinal variables). Analysis of changes in variables in T2 and T3 was done using generalised mixed models (for continuous outcome variables) or cumulative link mixed models (for ordinal variables). Additionally, Cohen's $f^{2}$ was used to calculate the clinical effect sizes. Analysis was performed in R for windows (version 3.5.3) (R Core Team, 2019). Differences were considered as statistically significant if the p-value was less or equal than 0.05 .

The intra- and inter-assays were calculated for determined parameters: BDNF, NGF, IL-6, IL-10 and NO. Intra-assay replicates were evaluated by calculating the coefficient of variation (CV) in \%. Since there is no consensus on the appropriate threshold for objective judgment of the reliability of a biological test, we have set up a threshold of $\mathrm{CV}<15 \%$ as revealing good reliability and a CV $<5 \%$ for very good reliability (according to Belzeaux et al., 2017). The inter-assay variation was also determined to measure the consistency of replicate samples between experiments. Inter $\% \mathrm{CV}$ is considered to be the best if $<15 \%$.

\section{Results}

\subsection{Level of cognitive functions at baseline (T1)}

All participants were classified with mild cognitive impairment based on MoCA test. There were no statistically significant differences between the participants in the experimental (mean=23.76 SD \pm 1.7 ) and control (mean=23.83; $\mathrm{SD} \pm 1.77)$ groups $(\mathrm{p}=0.89)$ in general cognitive functioning as presented in Table 1.

The detailed description of cognitive functions assessed by DemTect, SLUMS, TYM and FAS are additionally included in Table 2 . There were few minor statistically important differences between participants allocated into EG and CG like DemTect 3 "Supermarket: Semantic fluency" ( $p=0.04)$ (presented in Supplementary Table 1).

Table 2 Results obtained at baseline (T1)

\begin{tabular}{|c|c|c|c|c|}
\hline \multirow[t]{2}{*}{ Tool } & \multirow[t]{2}{*}{ Group } & \multicolumn{3}{|c|}{ T1 } \\
\hline & & $\begin{array}{l}\text { Mean } \\
\text { (SD) }\end{array}$ & $\begin{array}{l}\text { Median } \\
\left(\mathbf{Q}_{1} \cdot \mathbf{Q}_{3}\right)\end{array}$ & $p$ \\
\hline \multirow[t]{2}{*}{ DemTect Total } & EG & $11.7(3.52)$ & $12(9-14)$ & \multirow[t]{2}{*}{0.09} \\
\hline & CG & $13.07(2.73)$ & $12(11-15)$ & \\
\hline
\end{tabular}




\begin{tabular}{|c|c|c|c|c|}
\hline \multirow[t]{2}{*}{ Slums Total } & EG & $23.46(3.17)$ & $23(22-26)$ & \multirow[t]{2}{*}{$0.03 *$} \\
\hline & CG & $21.59(3.11)$ & $22(19-24)$ & \\
\hline \multirow[t]{2}{*}{ TYM Total } & EG & 45.03(3.16) & $45(44-48)$ & \multirow[t]{2}{*}{0.7} \\
\hline & CG & $45(3.77)$ & $46(43-47.5)$ & \\
\hline \multirow[t]{2}{*}{ FAS Total } & EG & $30.55(11.41)$ & $30(23-38)$ & \multirow[t]{2}{*}{0.89} \\
\hline & CG & $29.9(11.01)$ & $32(24-37)$ & \\
\hline \multirow[t]{2}{*}{ AIS } & EG & $31.97(6.59)$ & $34(27-37)$ & \multirow[t]{2}{*}{0.69} \\
\hline & CG & $30.45(9.09)$ & $34(26-37)$ & \\
\hline \multirow[t]{2}{*}{ GDS } & EG & $5.33(2.96)$ & $6(3-7)$ & \multirow[t]{2}{*}{0.09} \\
\hline & CG & $4.21(3.2)$ & $3(2-5)$ & \\
\hline \multirow[t]{2}{*}{ WHOQOL - physical } & EG & $24.49(3.59)$ & $24(22-27)$ & \multirow[t]{2}{*}{0.99} \\
\hline & CG & $24.59(4.25)$ & $24(22-27)$ & \\
\hline \multirow{2}{*}{ WHOQOL - psychological } & EG & $22.09(3.65)$ & $22(20-25)$ & \multirow[t]{2}{*}{0.81} \\
\hline & CG & $21.86(3.52)$ & $22(20-25)$ & \\
\hline \multirow[t]{2}{*}{ WHOQOL - social } & EG & $11.06(2.34)$ & $11(10-13)$ & \multirow[t]{2}{*}{0.36} \\
\hline & CG & $10.59(2.23)$ & $11(8-12)$ & \\
\hline \multirow[t]{2}{*}{ WHOQOL - environmental } & EG & $30.09(4.24)$ & $30(27-33)$ & \multirow[t]{2}{*}{0.20} \\
\hline & CG & $28.83(4.32)$ & $29(25-32)$ & \\
\hline \multirow[t]{2}{*}{ VAS 1 - vitality } & EG & $6.81(2.34)$ & $6.7(5.35-8.3)$ & \multirow[t]{2}{*}{0.74} \\
\hline & CG & $7.13(1.85)$ & $7.2(5.75-8.55)$ & \\
\hline \multirow[t]{2}{*}{ VAS $2-\operatorname{mood}$} & EG & $7.05(2.52)$ & $7(5.65-9.5)$ & \multirow[t]{2}{*}{0.75} \\
\hline & $\mathrm{CG}$ & $6.94(1.84)$ & $7.15(5.3-8.28)$ & \\
\hline \multirow[t]{2}{*}{ VAS 3 - sleep quality } & EG & $6.47(2.1)$ & $6.8(4.45-7.85)$ & \multirow[t]{2}{*}{0.79} \\
\hline & CG & $6.67(2.0)$ & $6.7(5.9-8.03)$ & \\
\hline
\end{tabular}

${ }^{*} p<0.05$

\subsection{Primary outcome measures}

The results show evidence for a statistically significant difference in assessment in cognitive functions in DemTect (time by group interaction $\mathrm{p}=0.01$ ) after $10 \mathrm{WBC}$ sessions (Table 3). The experimental group scored higher (T2) compared to baseline (T1), with an adjusted between group difference in mean score of 1.727 points. Cohen's $f^{2}$ calculation (0.24) indicated medium clinical effect size. There were no other significant differences in primary outcome measures between $\mathrm{T} 1$ and $\mathrm{T} 2$. The analysis of individual items of DemTect scale indicates significant differences between groups measured over time (T1 vs T2) in immediate recall (DemTect 1: 1.34 points, $\mathrm{p}=0.02$ ) (Supplementary Table 2). There were no statistically important differences between T1, T2 and T3 in SLUMS scores in EG in comparison to CG (Table 3).

\subsection{Secondary outcome measures}

\subsubsection{Cognitive functions}

There were no other significant differences in general cognitive functioning between T1, T2 and T3 (Table 3) measured with TYM. However, the results show evidence for a statistically significant difference in assessment in cognitive functions in Test Your Memory 1 - Orientation (T3 time by group interaction $\mathrm{p}=0.05$ ) after 2 weeks from the last WBC session. The experimental group scored higher (T3) compared to baseline (T1), with an adjusted between group difference in mean score of 1.97 points (Supplementary Table 2).

\subsubsection{Quality of life and mood}


Regarding quality of life, participants did not declare any statistically significant change in four domains measured with WHOQoL-BREF. However, there was a statistically significant improvement in the reduction of the level of depressive symptoms (WHOQoL-26) (time by group interaction $\mathrm{p}=0.04$ ) in T3 (Table 3). Moreover, the results show evidence for a statistically significant difference in assessment in WHOQoL-2 general health (time by group interaction $\mathrm{p}=0.02$ ) after $10 \mathrm{WBC}$ sessions (T2) and after 2 weeks from the last WBC session (T3) (time by group interaction $\mathrm{p}=0.02$ ) (Supplementary Table 2).

Participants from EG also reported significant improvement (T2 time and group $\mathrm{p}=0.02$; Cohen's $f^{2}=0.26$ ) in their mood (VAS 2) comparing to those from CG using VAS. Statistically significant changes in mood were not recorded in GDS. Table 3 presents detailed information.

Table 3 Linear mixed model analysis results $(T 1, T 2, T 3)$

\begin{tabular}{|c|c|c|c|c|c|}
\hline \multirow[t]{2}{*}{ Tool } & \multirow[t]{2}{*}{ Interaction description } & \multicolumn{3}{|c|}{$\begin{array}{l}\text { Linear mixed model } \\
\text { analysis } \\
\text { - interaction effect }\end{array}$} & \multirow[b]{2}{*}{ Cohen's $f^{2}$} \\
\hline & & Estimate & $\begin{array}{c}\text { Std } \\
\text { Error }\end{array}$ & $\begin{array}{c}p- \\
\text { value }\end{array}$ & \\
\hline \multirow[t]{6}{*}{ DemTect total } & (Intercept) & 13.07 & 0.61 & 0.00 & \\
\hline & $\mathrm{T} 2$ & 1.00 & 0.50 & 0.05 & \\
\hline & T3 & 1.90 & 0.53 & 0.00 & \\
\hline & Experimental group & -1.37 & 0.83 & 0.10 & \\
\hline & $\mathrm{T} 2$ time $\mathrm{x}$ Experimental group & 1.73 & 0.68 & 0.01 & \\
\hline & T3 time $x$ Experimental group & 0.56 & 0.71 & 0.43 & 0.24 \\
\hline \multirow[t]{6}{*}{ TYM total } & (Intercept) & 45.08 & 0.59 & 0.00 & \\
\hline & T2 & 0.31 & 0.59 & 0.60 & \\
\hline & T3 & 1.18 & 0.63 & 0.06 & \\
\hline & Experimental group & -0.05 & 0.80 & 0.95 & \\
\hline & $\mathrm{T} 2$ time $\mathrm{x}$ Experimental group & 0.87 & 0.80 & 0.28 & \\
\hline & T3 time x Experimental group & 1.30 & 0.83 & 0.12 & 0.15 \\
\hline \multirow[t]{6}{*}{ SLUMS total } & (Intercept) & 21.59 & 0.54 & 0.00 & \\
\hline & $\mathrm{T} 2$ & 1.31 & 0.49 & 0.01 & \\
\hline & T3 & 1.48 & 0.53 & 0.01 & \\
\hline & Experimental group & 1.87 & 0.74 & 0.01 & \\
\hline & $\mathrm{T} 2$ time $\mathrm{x}$ Experimental group & -0.01 & 0.67 & 0.99 & \\
\hline & T3 time x Experimental group & 0.87 & 0.70 & 0.22 & 0.13 \\
\hline \multirow[t]{6}{*}{ FAS } & (Intercept) & 29.90 & 2.19 & 0.00 & \\
\hline & $\mathrm{T} 2$ & 3.86 & 1.44 & 0.01 & \\
\hline & T3 & 4.89 & 1.57 & 0.00 & \\
\hline & Experimental group & 0.65 & 3.00 & 0.83 & \\
\hline & T2 time x Experimental group & 0.50 & 1.98 & 0.80 & \\
\hline & T3 time x Experimental group & -0.23 & 2.08 & 0.91 & 0.03 \\
\hline $\begin{array}{l}\text { WHOQoL }- \text { item } 1- \\
\text { quality of life }\end{array}$ & (Intercept) & 3.90 & 0.12 & 0.00 & \\
\hline
\end{tabular}




\begin{tabular}{|c|c|c|c|c|c|}
\hline & $\mathrm{T} 2$ & -0.14 & 0.12 & 0.24 & \\
\hline & T3 & -0.16 & 0.12 & 0.19 & \\
\hline & Experimental group & -0.02 & 0.16 & 0.91 & \\
\hline & $\mathrm{T} 2$ time $\mathrm{x}$ Experimental group & 0.23 & 0.16 & 0.15 & \\
\hline & $\mathrm{T} 3$ time $\mathrm{x}$ Experimental group & 0.32 & 0.17 & 0.06 & 0.19 \\
\hline \multirow{6}{*}{$\begin{array}{l}\text { WHOQoL - item } 26 \text { - } \\
\text { depressive symptoms }\end{array}$} & (Intercept) & 3.83 & 0.14 & 0.00 & \\
\hline & $\mathrm{T} 2$ & 0.03 & 0.13 & 0.79 & \\
\hline & T3 & -0.08 & 0.14 & 0.55 & \\
\hline & Experimental group & -0.16 & 0.19 & 0.40 & \\
\hline & $\mathrm{T} 2$ time $\mathrm{x}$ Experimental group & 0.24 & 0.18 & 0.19 & \\
\hline & T3 time $\mathrm{x}$ Experimental group & 0.39 & 0.19 & 0.04 & 0.26 \\
\hline \multirow[t]{6}{*}{ WHOQoL - physical } & (Intercept) & 24.59 & 0.79 & 0.00 & \\
\hline & $\mathrm{T} 2$ & 0.86 & 0.59 & 0.15 & \\
\hline & T3 & 0.71 & 0.64 & 0.27 & \\
\hline & Experimental group & -0.10 & 1.08 & 0.93 & \\
\hline & $\mathrm{T} 2$ time $\mathrm{x}$ Experimental group & 0.08 & 0.81 & 0.93 & \\
\hline & T3 time $\mathrm{x}$ Experimental group & 0.25 & 0.85 & 0.77 & 0.03 \\
\hline \multirow{6}{*}{$\begin{array}{l}\text { WHOQoL - } \\
\text { psychological }\end{array}$} & (Intercept) & 21.86 & 0.68 & 0.00 & \\
\hline & $\mathrm{T} 2$ & -0.07 & 0.47 & 0.88 & \\
\hline & T3 & 0.07 & 0.51 & 0.89 & \\
\hline & Experimental group & 0.23 & 0.93 & 0.81 & \\
\hline & $\mathrm{T} 2$ time $\mathrm{x}$ Experimental group & 0.89 & 0.65 & 0.17 & \\
\hline & $\mathrm{T} 3$ time $\mathrm{x}$ Experimental group & 1.12 & 0.68 & 0.10 & 0.17 \\
\hline \multirow[t]{6}{*}{ WHOQoL - social } & (Intercept) & 10.59 & 0.41 & 0.00 & \\
\hline & $\mathrm{T} 2$ & 0.14 & 0.29 & 0.64 & \\
\hline & T3 & -0.14 & 0.31 & 0.65 & \\
\hline & Experimental group & 0.47 & 0.57 & 0.40 & \\
\hline & $\mathrm{T} 2$ time $\mathrm{x}$ Experimental group & -0.08 & 0.40 & 0.85 & \\
\hline & $\mathrm{T} 3$ time $\mathrm{x}$ Experimental group & 0.40 & 0.41 & 0.33 & 0.11 \\
\hline \multirow{6}{*}{$\begin{array}{l}\text { WHOQoL - } \\
\text { environmental }\end{array}$} & (Intercept) & 28.83 & 0.82 & 0.00 & \\
\hline & $\mathrm{T} 2$ & 0.14 & 0.53 & 0.80 & \\
\hline & T3 & -0.35 & 0.57 & 0.54 & \\
\hline & Experimental group & 1.26 & 1.13 & 0.27 & \\
\hline & $\mathrm{T} 2$ time $\mathrm{x}$ Experimental group & 0.20 & 0.73 & 0.79 & \\
\hline & T3 time $\mathrm{x}$ Experimental group & 1.32 & 0.76 & 0.09 & 0.17 \\
\hline \multirow[t]{6}{*}{ AIS } & (Intercept) & 30.45 & 1.34 & 0.00 & \\
\hline & $\mathrm{T} 2$ & 2.66 & 1.48 & 0.08 & \\
\hline & T3 & 2.93 & 1.58 & 0.07 & \\
\hline & Experimental group & 1.52 & 1.84 & 0.41 & \\
\hline & $\mathrm{T} 2$ time $\mathrm{x}$ Experimental group & -0.90 & 2.03 & 0.66 & \\
\hline & T3 time $\mathrm{x}$ Experimental group & -1.78 & 2.11 & 0.40 & 0.08 \\
\hline \multirow[t]{6}{*}{ GSD } & (Intercept) & 4.21 & 0.60 & 0.00 & \\
\hline & $\mathrm{T} 2$ & 0.07 & 0.42 & 0.87 & \\
\hline & T3 & 0.23 & 0.45 & 0.62 & \\
\hline & Experimental group & 1.13 & 0.82 & 0.17 & \\
\hline & $\mathrm{T} 2$ time $\mathrm{x}$ Experimental group & -0.40 & 0.57 & 0.48 & \\
\hline & T3 time $\mathrm{x}$ Experimental group & -0.41 & 0.60 & 0.50 & 0.08 \\
\hline \multirow[t]{6}{*}{ VAS 1 - vitality } & (Intercept) & 7.13 & 0.91 & 0.00 & \\
\hline & $\mathrm{T} 2$ & -0.21 & 1.28 & 0.87 & \\
\hline & $\mathrm{T} 3$ & 0.52 & 1.28 & 0.69 & \\
\hline & Experimental group & -0.32 & 1.36 & 0.82 & \\
\hline & $\mathrm{T} 2$ time $\mathrm{x}$ Experimental group & 1.08 & 1.90 & 0.57 & \\
\hline & T3 time $\mathrm{x}$ Experimental group & 3.24 & 1.90 & 0.09 & 0.18 \\
\hline \multirow[t]{3}{*}{ VAS $2-\operatorname{mood}$} & (Intercept) & 6.94 & 0.37 & 0.00 & \\
\hline & $\mathrm{T} 2$ & 0.04 & 0.34 & 0.91 & \\
\hline & T3 & 0.59 & 0.34 & 0.08 & \\
\hline
\end{tabular}




\begin{tabular}{|l|l|r|r|r|r|}
\hline & Experimental group & 0.12 & 0.55 & 0.83 & \\
\hline & T2 time x Experimental group & 1.24 & 0.50 & $\mathbf{0 . 0 2}$ & 0.26 \\
\hline & T3 time x Experimental group & 0.93 & 0.50 & 0.07 & \\
\hline VAS 3 - sleep quality & (Intercept) & 6.66 & 0.40 & 0.00 & \\
\hline & T2 & 0.15 & 0.40 & 0.70 & \\
\hline & T3 & 0.48 & 0.40 & 0.24 & \\
\hline & Experimental group & -0.20 & 0.59 & 0.74 & \\
\hline & T2 time x Experimental group & 0.84 & 0.59 & 0.16 & 0.15 \\
\hline
\end{tabular}

\subsubsection{Blood measurements}

A significant $(\mathrm{p}<0.05)$ decrease of BDNF level in experimental group (EG) compared to control group (CG) was observed after the last $\left(10^{\text {th }}\right)$ session of WBC (T2). However, no significant effect on cytokines (IL-6, IL-10), NO and NGF concentration and the other laboratory parameters such as CRP, total cholesterol and prolactin, was observed (Table 4). The intra-assay variability (CV(\%) was determined for: $\operatorname{BDNF}(5.1 \% ; 4.6 \% ; 10.4 \% ; 4.4 \% ; 1.9 \%$ and $4.7 \%)$; NGF $(1.25 \%$ and $6.09 \%)$; IL-10 $(2.6 \% ; 12 \% ; 8.4 \% ; 7.9 \% ; 6.1 \%$ and $13.3 \%)$, IL-6 $(0.3 \% ; 9.1 \% ; 12.3 \% ; 13 \%$ and $19.22 \%)$ and NO $(4.5 \% ; 4.2 \% ; 10 \% ; 11.2 \%$ and $12.3 \%)$. The inter-assay variations were $5.1 \%$ for BDNF; $3.6 \%$ for NGF, $8.3 \%$ for IL-10, 10,78\% for IL-6 and $8.4 \%$ for NO.

Table 4. Biochemical changes after WBC in the experimental and control groups.

\begin{tabular}{|c|c|c|c|c|c|c|c|c|c|c|}
\hline Parameter & Group & $\begin{array}{c}\text { T1 } \\
\text { Median }(\mathbf{Q 1 - Q 3 )} \\
\text { Mean } \pm \text { SD }\end{array}$ & $\begin{array}{c}\text { T2 } \\
\text { Median }(Q 1-Q 3) \\
\text { Mean } \pm \text { SD }\end{array}$ & multifactor & $\boldsymbol{\beta}$ & St.Err. & df & $\begin{array}{c}\mathbf{t} \\
\text { value }\end{array}$ & $\begin{array}{c}\mathbf{p} \\
\text { value }\end{array}$ & $\begin{array}{c}\text { Coh } \\
\text { en's } \\
f^{2}\end{array}$ \\
\hline \multirow{4}{*}{$\begin{array}{c}\text { IL-6 } \\
\text { (pg/ml) }\end{array}$} & \multirow[t]{2}{*}{ CG } & $0.00(0-1.99)$ & $0.00(0-0.06)$ & \multirow[t]{2}{*}{$\begin{array}{l}\text { T2 (CG vs } \\
\text { EG) }\end{array}$} & \multirow[t]{2}{*}{-0.43} & \multirow[t]{2}{*}{1.15} & \multirow[t]{2}{*}{57.55} & \multirow[t]{2}{*}{-0.38} & \multirow[t]{2}{*}{0.71} & \multirow[t]{2}{*}{0.10} \\
\hline & & $4.56 \pm 11.98$ & $3.24 \pm 9.78$ & & & & & & & \\
\hline & \multirow[t]{2}{*}{ EG } & $2.96(0-9.06)$ & $4.74(0-6.86)$ & \multirow[t]{2}{*}{ EG (T1-T2) } & \multirow[t]{2}{*}{1.99} & \multirow[t]{2}{*}{2.21} & \multirow[t]{2}{*}{57.14} & \multirow[t]{2}{*}{0.90} & \multirow[t]{2}{*}{0.37} & \\
\hline & & $5.87 \pm 8.74$ & $6.24 \pm 7.20$ & & & & & & & \\
\hline \multirow{4}{*}{$\begin{array}{l}\text { IL-10 } \\
\text { (pg/ml) }\end{array}$} & \multirow[t]{2}{*}{ CG } & $7.39(3.49-12.71)$ & $7.34(4.14-13.53)$ & \multirow{2}{*}{$\begin{array}{l}\text { T2 (CG vs } \\
\text { EG) }\end{array}$} & \multirow[t]{2}{*}{-1.92} & \multirow[t]{2}{*}{2.19} & \multirow[t]{2}{*}{60.00} & \multirow[t]{2}{*}{-0.88} & \multirow[t]{2}{*}{0.39} & 0.10 \\
\hline & & $8.99 \pm 6.88$ & $8.81 \pm 5.91$ & & & & & & & \\
\hline & \multirow[t]{2}{*}{ EG } & $5.88(4.50-8.02)$ & $7.24(5.95-9.15)$ & \multirow[t]{2}{*}{$\mathrm{EG}(\mathrm{T} 1-\mathrm{T} 2)$} & \multirow[t]{2}{*}{0.47} & \multirow[t]{2}{*}{2.67} & \multirow[t]{2}{*}{59.00} & \multirow[t]{2}{*}{0.18} & \multirow[t]{2}{*}{0.86} & \\
\hline & & $11.12 \pm 24.64$ & $7.62 \pm 3.18$ & & & & & & & \\
\hline \multirow{4}{*}{$\begin{array}{l}\text { NO } \\
(\mathbf{n M})\end{array}$} & \multirow[t]{2}{*}{ CG } & $\begin{array}{c}2288.83(1086.08- \\
4061.25)\end{array}$ & $\begin{array}{c}2088.11(910.28- \\
3704.99)\end{array}$ & \multirow[t]{2}{*}{$\begin{array}{l}\text { T2 (CG vs } \\
\text { EG) }\end{array}$} & \multirow[t]{2}{*}{496.97} & 419.50 & 48.00 & 1.19 & 0.24 & 0.17 \\
\hline & & $2613.64 \pm 1993$ & $2510.48 \pm 2139.73$ & & & & & & & \\
\hline & EG & $\begin{array}{l}\text { 1081.57(565.81- } \\
3543.33)\end{array}$ & $\begin{array}{c}1980.68(1079.49- \\
4120.25)\end{array}$ & $\mathrm{EG}(\mathrm{T} 1-\mathrm{T} 2)$ & 916.17 & $\begin{array}{c}1035.9 \\
0\end{array}$ & 47.00 & 0.88 & 0.38 & \\
\hline & & $3039.71 \pm 4190.4$ & $3916.75 \pm 4953.60$ & & & & & & & \\
\hline & CG & $\begin{array}{c}108.02(78.17- \\
169.77)\end{array}$ & $74.93(51.30-179.03)$ & $\begin{array}{c}\text { T2 (CG vs } \\
\text { EG) }\end{array}$ & -58.25 & 23.09 & 51.00 & -2.52 & 0.015 & 0.15 \\
\hline$(\mathrm{pg} / \mathrm{ml})$ & & $178.90 \pm 190.77$ & $144.45 \pm 193.37$ & & & & & & & \\
\hline & EG & $94.74(59.79-203.82)$ & $64.56(39.14-130.66)$ & EG (T1-T2) & -27.73 & 40.06 & 50.00 & -0.69 & 0.49 & \\
\hline & & $175.93 \pm 173.68$ & $91.95 \pm 74.18$ & & & & & & & \\
\hline
\end{tabular}




\begin{tabular}{|c|c|c|c|c|c|c|c|c|c|c|}
\hline \multirow[t]{2}{*}{$\begin{array}{c}\text { NGF } \\
(\mathrm{pg} / \mathrm{ml})\end{array}$} & CG & $\begin{array}{c}0(0-0) \\
3.901 \pm 13.41\end{array}$ & $\begin{array}{c}0(0-0) \\
36.12 \pm 123.05\end{array}$ & $\begin{array}{l}\mathrm{T} 2 \text { (CG vs } \\
\text { EG) }\end{array}$ & 12.58 & 13.35 & 35.00 & 0.94 & 0.35 & 0.21 \\
\hline & EG & $\begin{array}{c}0(0-0) \\
8.31 \pm 25.48\end{array}$ & $\begin{array}{c}0(0-0) \\
6.86 \pm 24.62\end{array}$ & EG (T1-T2) & -12.43 & 14.91 & 34.00 & -0.83 & 0.41 & \\
\hline \multirow[t]{2}{*}{$\begin{array}{c}\text { CRP } \\
{[\mathrm{mg} / \mathrm{l}]}\end{array}$} & CG & $\begin{array}{c}0.73(0.41-2.30) \\
1.56 \pm 1.69\end{array}$ & $\begin{array}{c}0.84(0.36-3.20) \\
1.66 \pm 1.70\end{array}$ & $\begin{array}{c}\text { T2 (CG vs } \\
\text { EG) }\end{array}$ & 0.15 & 0.17 & 61.00 & 0.85 & 0.40 & 0.04 \\
\hline & EG & $\begin{array}{c}1.16(0.51-2.12) \\
1.76 \pm 1.71\end{array}$ & $\begin{array}{c}1.41(0.79-2.27) \\
1.95 \pm 1.65\end{array}$ & EG (T1-T2) & 0.24 & 0.39 & 60.00 & 0.62 & 0.54 & \\
\hline \multirow[t]{2}{*}{$\begin{array}{c}\text { Total } \\
\text { cholesterol } \\
{[\mathrm{mg} / \mathrm{dl}]}\end{array}$} & CG & $\begin{array}{l}219(197-251) \\
231.41 \pm 56.57\end{array}$ & $\begin{array}{l}214(188-247) \\
227.00 \pm 55.82\end{array}$ & $\begin{array}{c}\text { T2 (CG vs } \\
\text { EG) }\end{array}$ & -1.65 & 3.42 & 61.00 & -0.48 & 0.63 & 0.10 \\
\hline & EG & $\begin{array}{l}212(188-246) \\
215.52 \pm 41.95\end{array}$ & $\begin{array}{l}212(199-242) \\
216.30 \pm 38.05\end{array}$ & EG (T1-T2) & -13.30 & 11.79 & 60.00 & -1.13 & 0.26 & \\
\hline \multirow[t]{2}{*}{$\begin{array}{c}\text { Prolactin } \\
\text { [ng/ml] }\end{array}$} & CG & $\begin{array}{c}6.26(5.70-11.10) \\
8.43 \pm 4.38\end{array}$ & $\begin{array}{c}5.70(5.16-11.33) \\
8.41 \pm 4.76\end{array}$ & $\begin{array}{c}\text { T2 (CG vs } \\
\text { EG) }\end{array}$ & -0.64 & 0.69 & 38.00 & -0.92 & 0.37 & 0.08 \\
\hline & EG & $\begin{array}{c}11.05(8.37-15.09) \\
12.23 \pm 5.71\end{array}$ & $\begin{array}{c}10.56(8.14-13.15) \\
11.38 \pm 5.30\end{array}$ & $\mathrm{EG}(\mathrm{T} 1-\mathrm{T} 2)$ & 3.38 & 1.77 & 37.00 & 1.91 & 0.06 & \\
\hline
\end{tabular}

$f^{2} \geq 0.02, f^{2} \geq 0.15$, and $f^{2} \geq 0.35$ represent small, medium and large effect sizes (respectively) (Cohen, 1988).

\section{Discussion}

The study results indicate that Whole-Body Cryotherapy may increase the performance of cognitive functions among people with mild cognitive impairment. Our results highlight that participants from experimental group showed a significant improvement in general cognitive functioning (DemTect total score) as well as in episodic memory measured by immediate recall task (DemTect 1) compared to control group after participating in WBC sessions. An improvement in the orientation (Test Your Memory: orientation) among participants subjected to WBC was noted. These results are in line our previous study (Rymaszewska et al., 2018). However, the important value of RCT design should be emphasised as our earlier report focused only on the effects within participants undergoing WBC without comparison to the sham group. Potentially, the learning processes (including the "practice effect') (Donovan and Radosevich, 1999) could also be responsible for the effect seen in the previous study. Nevertheless, these analyses clearly show the effect seen in the interaction between time and group. Thus, present conclusions are of great importance. To the best of our knowledge, this is the first report considering the impact of WBC on cognitive functions as a result of the RCT study in MCI. Therefore, it is difficult to compare the results of our study with other non-pharmacological interventions such as physical or cognitive training applicable among patients with MCI as the mechanisms of action are having different grounds. However, it should be noted that there are many 
reports highlighting the role of behavioural interventions/stimulations, including exercise, in improving the cognitive functioning of people with cognitive deficits (Colcombe and Kramer, 2003; Nuzum et al., 2020). One study is known to date that also evaluated the concept of applying low temperatures to improve cognitive function, however this study was different in terms of both the study population and the intervention used (Gonzales et al., 2017). In their study, Gonzales et al. (2017), aimed to investigate whether wearing a cooling vest during a physical training program could increase the cognitive and physical capacities of patients with multiple sclerosis. In this study, the combination of physical training together with cooling vest had a positive influence on cognition (in terms of verbal fluency) as well as in executive functions measured with Trail Making Test A. The Gonzales study highlights one important feature of interventions that improve cognitive function - its multimodality. Similar observations resulted from a meta-analysis in which the authors mainly considered the effect of cognitive training in MCI patients. They found significant, moderate effects for multicomponent training as well as multidomain focused strategies (Sherman et al., 2017). Therefore, joined programs, consisting of a combination of interventions having different neurostimulatory mechanisms, seem to be of particular importance among MCI patients. Especially since WBC, apart from significantly influencing the improvement of cognitive functions, has again confirmed influence on mood. Participants from experimental group rated their mood higher (on visual analogue scale), which differed significantly from those who were subjected to the placebo group. Significant changes in mood were not recorded in GDS. However, it should be emphasized that the mood assessed using VAS is related to well-being in general. In turn, the GDS scale measured mood and other depressive symptoms that are associated with the depressive disorder. The study involved people without depressive symptoms, which is why no significant changes in GDS were expected. Given the multimodal impact of WBC on cognitive function and mood it seems promising to combined existing behavioural and cognitive trainings together with WBC, thus adding another potential mechanism of neurostimulation.

Recent studies indicate that low temperatures may have a protective influence on the central nervous system (Dietrich and Bramlett, 2010; Jackson and Kochanek, 2019). Therefore, finding the explanation of the possible WBC impact on anti-inflammatory and neuroprotective mechanisms - and its connection with the modulation of cognitive functions - may prove important (Misiak and Kiejna, 2012; Rymaszewska et al., 2018). A number of studies have investigated peripheral inflammatory indices, including plasma cytokines, chemokines, acute phase proteins, activated complement factors, free radicals and related molecules according to mild cognitive impairment (MCI), defined as a predementia syndrome, and Alzheimer's disease (AD) (Faria et al., 2014; Janoutová et al., 2015; Magaki et al., 2007; Saleem et al., 2015). Also, the possible involvement of neurotrophins such as brainderived neurotrophic factor (BDNF) and nerve growth factor (NGF) are considered (Angelucci, 2009; Faria et al., 2014). 
In the present study, we observed that the applied Whole-Body Cryotherapy did not affect the concentration of the measured cytokines, both pro-inflammatory IL-6 and anti-inflammatory IL-10, measured in MCI patients' plasma before and after therapy. There was also no significant impact on NGF level and nitric oxide production. Comparable results were presented by Sadura-Sieklucka et al. (2019), where no differences in the concentrations of cytokine tested were observed in the serum of rheumatoid arthritis patients before and after cryotherapy. However, this is in contrast to the results obtained by Gizinska et al. (2015), who presented that WBC exerted anti-inflammatory local and systemic effects. In blood obtained from rheumatoid arthritis patients a significant decrease of IL-6 and TNF- $\alpha$ was shown after cryotherapy (Gizińska et al., 2015). Exposure to cold also significantly enhanced the concentration of the anti-inflammatory cytokine IL-10 (Banfi et al., 2009).

Moreover, we observed that the applied WBC did not affect the concentration of CRP measured in serum. Comparable results were presented by Istrati et al. (2010) who showed that WBC in patients with rheumatoid arthritis and osteoarthritis did not reduce CRP levels. However, this is in contrast to the results obtained by Sadura-Sieklucka et al. (2019) who showed that WBC exerts local and systemic effects. Additionally, the stimulus for CRP production is an increase in IL-6 concentration (Bloomfield et al., 2019).

There are number of reports indicating that changes in level of peripheral cytokines can be connected with the presence of a pro-inflammatory process accompanying neurodegenerative diseases such as AD (Bermejo et al., 2008; Brosseron et al., 2014). While associations between MCI and inflammatory markers have been documented, many reports are controversial or inconclusive, particularly those presenting data investigating cytokines like TNFa, IL-6 or IL-10 (Brosseron et al., 2014; Su et al., 2019). Some studies indicated no significant changes in inflammatory markers at the MCI stage of cognitive decline (Sadura-Sieklucka et al., 2019; Saleem et al., 2015).

Literature data also suggests the participation of CRP in the development of MCI, however, there are no other reference interval values for people with MCI. It is true that there is evidence of increased CRP values in people with type II diabetes and MCI (Gorska-Ciebiada et al., 2015a, 2015b). However, in our study participants, CRP is within the reference values of healthy people (Dembińska-Kieć and Naskalski, 2010), therefore the measured CRP levels do not indicate a developing inflammatory response. We did not observe the impact of WBC on cytokine level in plasma and serum CRP concentration of MCI patients treated with WBC. Our previous results showed that cryotherapy significantly improves immunological status of whole blood of MCI patients in response to amyloid beta 42 by modulating the intensity of inflammatory response (Rymaszewska et al., 2018).

Unexpectedly, significant decrease in BDNF level was observed in Examined Group (EG) compared to the Control Group (CG) (T2 (EG vs CG) p $\leq 0.05$ ) (Table 4). There is some experimental evidence that peripheral BDNF level is significantly higher in MCI patients and $\mathrm{AD}$ patients, when compared to the healthy control (Angelucci, 2009; Faria et al., 2014; Kim et al., 2017). Circulating BDNF comes 
from a number of peripheral sources as activated immune cells: $\mathrm{T}$ cells, $\mathrm{B}$ cells, monocytes or platelets. BDNF secreted by immune cells is bioactive and may support neuronal survival (Karege et al., 2005; Kerschensteiner et al., 1999). BDNF may also derive from neurons and glial cells. Indeed, some experimental work suggests that the blood-brain barrier is permeable to the neurotrophins (Pan et al., 1998; Poduslo and Curran, 1996).

Moreover, peripheral BDNF seems to reflect neural viability and integrity in healthy humans (Lang et al., 2007) as well as widespread brain amyloidosis (Teixeira et al., 2010). Previous studies have suggested that an increase of BDNF in MCI patients may reflect a compensatory repair mechanism activated in response to up- regulated inflammatory response in early stage of neurodegeneration in brain (Kim et al., 2017; Teixeira et al., 2010). Thus, observed reduction of BDNF level in this study may suggests that cold exposure down-regulates inflammatory processes.

Second, we can speculate that it can be partially depends on the impact of WBC on activity and/or immune status of peripheral blood cells (Pournot et al., 2011). As was shown by Kerschensteiner et al. (1999), BDNF can be secreted by immune cells in response to inflammatory stimuli. One of them can be abnormal form of amyloid $\beta$ (A $\beta$ ) which is one of the pathological factors in MCI and AD. Considering the inhibitory impact of WBC on inflammation and on APP processing in MCI patients (resulting the inhibition of production of abnormal form of $A \beta$ ) the down-regulated secretion of BDNF might be observed.

The following aspects should also be discussed while analysing the results of our study. Based on recently published data (Bermejo et al., 2008), we expected to show a significant modulation of inflammatory factors production in participants with MCI undergoing whole-body cryotherapy. However, no differences in levels of IL-6, IL-10, NGF and NO in plasma of both, the control and experimental, groups was shown. This may be due to the fact that the level of the tested inflammatory factors in plasma of MCI patients is comparable to that observed in plasma of normal control among older adults, which was previously observed by other researchers (Bermejo et al., 2008; Boccardi et al., 2019; Leung et al., 2013).

Our research was conducted only on people with MCI (both control and experimental groups). Therefore, we did not have a comparison within the healthy older adults control group which could provide information about the physiological level of tested biochemical parameters in potentially healthy seniors. These data would indicate whether the level of cytokines or BDNF in the group of patients with MCI is different from the level detected in the blood of healthy elderly people. Although the concentration of cytokines or BDNF in plasma of healthy people were published in many papers, those levels are very divergent.

Differences between the technical approaches reported in different studies, (e.g different ELISA kits do not give identical absolute values of the same analyte, plasma bio-banking conditions and sample handling may significantly affect the results of cytokine detection, standardisation between research groups should also be considered and patient collective characterisation) could explain our results (for 
references see Bathina and Das, 2015; Brosseron et al., 2014). Therefore, we cannot relate the results of our analyses to published data due to the risk of drawing false conclusions. Another explanation of results obtained for WBC-treated MCI patients is that the assumed treatment time (10 WBC sessions), may be insufficient to achieve a significant reduction of potential inflammatory processes.

\subsection{Study limitations}

The described study has also some limitations which should be taken into account. We did not collect data which would allow us to diagnose the MCI type. Additionally, we did use the same screening tests to measure changes before and after WBC. Therefore, some of the results in both experimental and control groups could be explained by the 'practise effect' (Donovan and Radosevich, 1999), described earlier in the text, as participants were provided with the same cognitive tasks at T1, T2 and T3. Using methods with existing alternative versions (i.e. MoCA or The Cambridge Neuropsychological Test Automated Battery - CANTAB) (Nasreddine et al., 2005; Robbins et al., 1994) could provide more accurate results.

The study sample for RTC design was relatively small. Obtained small and medium clinical effect sizes, based on Cohen's $f^{2}$ indicated that the study would require much more observation per group to show statistically significant differences with power of 0.8 (Cohen, 1988). Those calculations need to be taken into account in further studies planning. However, recruitment of target sample among older people with no WBC contraindications like hypertension and other diseases (Rubio-Guerra and DuranSalgado, 2015) is challenging. Additionally, WBC is a popular treatment for arthritis (Gizińska et al., 2015; Reginster, 2002) in Poland (another common condition among older adults) and previous use of WBC was our additional exclusion criteria.

Currently, there is a need to investigate the effect of placebo groups with sub-zero temperatures used. It is the closest way to perform almost identical conditions for WBC sessions and was also used in other randomised-controlled trials exploring WBC effects (Rymaszewska et al., 2020). However, it requires further investigation.

\section{Conclusions}

The current study showed that whole-body cryotherapy may increase the performance of cognitive functions measured with psychological tests. It seems promising to combine WBC with existing behavioural and cognitive trainings in the future studies investigating early interventions methods in MCI. The study did not provide sufficient information about WBC regulatory role in oxidative status and immunological response in MCI patients. Further study is required in this area. 


\section{AUTHORS' CONTRIBUTION}

Study design: BS, DS, KL, ET and JR. Recruitment and initial screening of participants: JR, KL, BS, TP, and ET. Blood parameters analysis: SP, IK, LP-S and AZ. Other data analysis: KL, DS, BS, JER and JR. Manuscript writing: JR, KL, DS, AZ, and BS. Supervising and final version: JR, DS. All authors have approved the final manuscript.

\section{ACKNOWLEDGEMENTS}

Authors would like to thank people from Creator Sp. z o.o., especially Mr. Adam Józefowicz (Chairman of the Board), Ms. Jolanta Malinowska (Proxy of the Board-Promotion and Marketing Director), and Ms. Daniela Zielińska for their kind assistance. We also acknowledge Dr Michael Todorovic's help in ensuring the correct use of English in this manuscript.

\section{CONFLICT OF INTEREST}

\section{None}

\section{FUNDING}

The study was evaluated and funded by the Ministry of Science and Higher Education (registration number ST.C230.14.079 (earlier ST-842), awarded to the Department of Psychiatry, Wroclaw Medical University, within the framework of research aimed at promoting young scientists in cooperation with the company Creator Sp. z o.o. in Wrocław, Poland. The funding institution had no role in the study design, collection, analysis or interpretation of the data, writing the manuscript, or the decision to submit the paper for publication. 


\section{REFERENCES}

Albiński, R., Kleszczewska-Albińska, A., Bedyńska, S., 2011. [Geriatric Depression Scale (GDS). Validity and reliability of different versions of the scale--review]. Psychiatr. Pol. 45, 555-62.

Angelucci, F., 2009. Alzheimer's Disease (AD) and Mild Cognitive Impairment (MCI) Patients are Characterized by Increased BDNF Serum Levels. Curr. Alzheimer Res. 999, 1-6. https://doi.org/10.2174/1567209197155462050

Banfi, G., Melegati, G., Barassi, A., Dogliotti, G., Melzi d'Eril, G., Dugué, B., Corsi, M.M., 2009. Effects of whole-body cryotherapy on serum mediators of inflammation and serum muscle enzymes in athletes. J. Therm. Biol. https://doi.org/10.1016/j.jtherbio.2008.10.003

Bathina, S., Das, U.N., 2015. Brain-derived neurotrophic factor and its clinical Implications. Arch. Med. Sci. https://doi.org/10.5114/aoms.2015.56342

Belzeaux, R., Lefebvre, M.-N., Lazzari, A., Le Carpentier, T., Consoloni, J.-L., Zendjidjian, X., Abbar, M., Courtet, P., Naudin, J., Boucraut, J., Gressens, P., Glaichenhaus, N., Ibrahim, E.C., 2017. How to: Measuring blood cytokines in biological psychiatry using commercially available multiplex immunoassays. Psychoneuroendocrinology 75, 72-82. https://doi.org/10.1016/j.psyneuen.2016.10.010

Bermejo, P., Martín-Aragón, S., Benedí, J., Susín, C., Felici, E., Gil, P., Ribera, J.M., Villar, Á.M., 2008. Differences of peripheral inflammatory markers between mild cognitive impairment and Alzheimer's disease. Immunol. Lett. 117, 198-202. https://doi.org/10.1016/j.imlet.2008.02.002

Bloomfield, M., Parackova, Z., Cabelova, T., Pospisilova, I., Kabicek, P., Houstkova, H., Sediva, A., 2019. Anti-IL6 Autoantibodies in an Infant With CRP-Less Septic Shock. Front. Immunol. 10, 2629. https://doi.org/10.3389/fimmu.2019.02629

Boccardi, V., Paolacci, L., Remondini, D., Giampieri, E., Poli, G., Curti, N., Cecchetti, R., Villa, A., Ruggiero, C., Brancorsini, S., Mecocci, P., 2019. Cognitive Decline and Alzheimer's Disease in Old Age: A Sex-Specific Cytokinome Signature. J. Alzheimer's Dis. 72, 911-918. https://doi.org/10.3233/JAD-190480

Bouzigon, R., Grappe, F., Ravier, G., Dugue, B., 2016. Whole- and partial-body cryostimulation/cryotherapy: Current technologies and practical applications. J. Therm. Biol. 61, 67-81. https://doi.org/10.1016/j.jtherbio.2016.08.009

Brosseron, F., Krauthausen, M., Kummer, M., Heneka, M.T., 2014. Body fluid cytokine levels in mild cognitive impairment and Alzheimer's disease: a comparative overview. Mol. Neurobiol. 50, 534-44. https://doi.org/10.1007/s12035-014-8657-1

Brown, J., Pengas, G., Dawson, K., Brown, L.A., Clatworthy, P., 2009. Self administered cognitive screening test (TYM) for detection of Alzheimer's disease: Cross sectional study. BMJ 338, 1426-1428. https://doi.org/10.1136/bmj.b2030

Cohen, J., 1988. Statistical power analysis for the behavioral sciences, 2nd ed. Lawrence Earlbaum Associates, Hillsdale.

Colcombe, S., Kramer, A.F., 2003. Fitness effects on the cognitive function of older adults: A metaanalytic study. Psychol. Sci. 14, 125-130. https://doi.org/10.1111/1467-9280.t01-1-01430

Dembińska-Kieć, A., Naskalski, J.W., 2010. Diagnostyka laboratoryjna z elementami biochemii klinicznej [Laboratory Diagnostics with Elelements of Clinical Biochemistry]. Urban \& Partner, Wroclaw.

Dietrich, W.D., Bramlett, H.M., 2010. The evidence for hypothermia as a neuroprotectant in traumatic brain injury. Neurotherapeutics 7, 43-50. https://doi.org/10.1016/j.nurt.2009.10.015

Donovan, J.J., Radosevich, D.J., 1999. A meta-analytic review of the distribution of practice effect: Now you see it, now you don't. J. Appl. Psychol. 84, 795-805. https://doi.org/10.1037/00219010.84.5.795

Faria, M.C., Gonçalves, G.S., Rocha, N.P., Moraes, E.N., Bicalho, M.A., Gualberto Cintra, M.T., Jardim de Paula, J., José Ravic de Miranda, L.F., Clayton de Souza Ferreira, A., Teixeira, A.Ô.L., Gomes, K.B., Carvalho, M. das G., Sousa, L.P., 2014. Increased plasma levels of BDNF and inflammatory markers in Alzheimer's disease. J. Psychiatr. Res. 53, 166-172. https://doi.org/10.1016/j.jpsychires.2014.01.019

Fischer-Altevogt, L., Calabrese, P., Kalbe, E., Kessler, J., 2002. DemTect: a new diagnostic too the detection of dementia. Rev. Geriatr. 27, 437-444.

Gauthier, S., Reisberg, B., Zaudig, M., Petersen, R.C., Ritchie, K., Broich, K., Belleville, S., Brodaty, 
H., Bennett, D., Chertkow, H., Cummings, J.L., de Leon, M., Feldman, H., Ganguli, M., Hampel, H., Scheltens, P., Tierney, M.C., Whitehouse, P., Winblad, B., 2006. Mild cognitive impairment. Lancet. https://doi.org/10.1016/S0140-6736(06)68542-5

Gizińska, M., Rutkowski, R., Romanowski, W., Lewandowski, J., Straburzyńska-Lupa, A., 2015. Effects of Whole-Body Cryotherapy in Comparison with Other Physical Modalities Used with Kinesitherapy in Rheumatoid Arthritis. Biomed Res. Int. 2015, 1-7. https://doi.org/10.1155/2015/409174

Gonzales, B., Chopard, G., Charry, B., Berger, E., Tripard, J., Magnin, E., Groslambert, A., 2017. Effects of a Training Program Involving Body Cooling on Physical and Cognitive Capacities and Quality of Life in Multiple Sclerosis Patients: A Pilot Study. Eur. Neurol. 78, 71-77. https://doi.org/10.1159/000477580

Gorska-Ciebiada, M., Saryusz-Wolska, M., Borkowska, A., Ciebiada, M., Loba, J., 2015a. Serum levels of inflammatory markers in depressed elderly patients with diabetes and mild cognitive impairment. PLoS One 10, 120433. https://doi.org/10.1371/journal.pone.0120433

Gorska-Ciebiada, M., Saryusz-Wolska, M., Borkowska, A., Ciebiada, M., Loba, J., 2015b. C-reactive protein, advanced glycation end products, and their receptor in type 2 diabetic, elderly patients with mild cognitive impairment. Front. Aging Neurosci. 7, 29. https://doi.org/10.3389/fnagi.2015.00209

Hamilton, M., 1960. A rating scale for depression. J. Neurol. Neurosurg. Psychiatry 23, 56-62.

Holsinger, R.M.D., Schnarr, J., Henry, P., Castelo, V.T., Fahnestock, M., 2000. Quantitation of BDNF mRNA in human parietal cortex by competitive reverse transcription-polymerase chain reaction: Decreased levels in Alzheimer's disease. Mol. Brain Res. 76, 347-354. https://doi.org/10.1016/S0169-328X(00)00023-1

Istrati, J., Głuszko, P., Suszko, R., Iwaniec, T., 2010. Whole-body cryotherapy decreases fibrinolytic activity in blood of patients with rheumatoid arthritis and patients with osteoarthritis. Reumatologia 48, 171-176.

Jackson, T.C., Kochanek, P.M., 2019. A New Vision for Therapeutic Hypothermia in the Era of Targeted Temperature Management: A Speculative Synthesis. Ther. Hypothermia Temp. Manag. 9, 13-47. https://doi.org/10.1089/ther.2019.0001

Janoutová, J., Šerý, O., Hosák, L., Janout, V., 2015. IS MILD COGNITIVE IMPAIRMENT A PRECURSOR OF ALZHEIMER'S DISEASE? SHORT REVIEW, Cent Eur J Public Health.

Jaracz, K., Kalfoss, M., Gorna, K., Bączyk, G., 2006. Quality of life in Polish respondents: psychometric properties of the Polish WHOQOL - Bref. Scand. J. Caring Sci. 20, 251-260. https://doi.org/10.1111/j.1471-6712.2006.00401.x

Juczyński, Z., 2001. Narzędzia pomiaru w promocji i psychologii zdrowia. Pracownia Testów Psychologicznych Polskiego Towarzystwa Psychologicznego.

Kanecki, K., Tyszko, P., 2016. Fibromyalgia in general practice. Forum Med. Rodz. 10, 59-65.

Karege, F., Bondolfi, G., Gervasoni, N., Schwald, M., Aubry, J.M., Bertschy, G., 2005. Low BrainDerived Neurotrophic Factor (BDNF) levels in serum of depressed patients probably results from lowered platelet BDNF release unrelated to platelet reactivity. Biol. Psychiatry 57, 1068-1072. https://doi.org/10.1016/j.biopsych.2005.01.008

Kerschensteiner, M., Gallmeier, E., Behrens, L., Leal, V.V., Misgeld, T., Klinkert, W.E.F., Kolbeck, R., Hoppe, E., Oropeza-Wekerle, R.L., Bartke, I., Stadelmann, C., Lassmann, H., Wekerle, H., Hohlfeld, R., 1999. Activated human T cells, B cells, and monocytes produce brain-derived neurotrophic factor in vitro and in inflammatory brain lesions: A neuroprotective role of inflammation? J. Exp. Med. 189, 865-870. https://doi.org/10.1084/jem.189.5.865

Kim, B.Y., Lee, S.H., Graham, P.L., Angelucci, F., Lucia, A., Pareja-Galeano, H., Leyhe, T., Turana, Y., Lee, I.R., Yoon, J.H., Shin, J. Il, 2017. Peripheral Brain-Derived Neurotrophic Factor Levels in Alzheimer's Disease and Mild Cognitive Impairment: a Comprehensive Systematic Review and Meta-analysis. Mol. Neurobiol. 54, 7297-7311. https://doi.org/10.1007/s12035-016-0192-9

Kim, J.Y., Kim, D.H., Kim, J.H., Lee, D., Jeon, H.B., Kwon, S.J., Kim, S.M., Yoo, Y.J., Lee, E.H., Choi, S.J., Seo, S.W., Lee, J.I., Na, D.L., Yang, Y.S., Oh, W., Chang, J.W., 2012. Soluble intracellular adhesion molecule-1 secreted by human umbilical cord blood-derived mesenchymal stem cell reduces amyloid-B plaques. Cell Death Differ. 19, 680-691. https://doi.org/10.1038/cdd.2011.140 
Lang, U.E., Hellweg, R., Seifert, F., Schubert, F., Gallinat, J., 2007. Correlation Between Serum Brain-Derived Neurotrophic Factor Level and An In Vivo Marker of Cortical Integrity. Biol. Psychiatry 62, 530-535. https://doi.org/10.1016/j.biopsych.2007.01.002

Leung, R., Proitsi, P., Simmons, A., Lunnon, K., Güntert, A., Kronenberg, D., Pritchard, M., Tsolaki, M., Mecocci, P., Kloszewska, I., Vellas, B., Soininen, H., Wahlund, L.O., Lovestone, S., 2013. Inflammatory Proteins in Plasma Are Associated with Severity of Alzheimer's Disease. PLoS One 8, 64971. https://doi.org/10.1371/journal.pone.0064971

Lubkowska, A., 2013. Therapeutic application of cryotherapy in chronic diseases - clinical practice [Zastosowanie krioterapii w chorobach przewlekłych]. Fam. Med. Prim. Care Rev. 15, 233-239.

Magaki, S., Mueller, C., Dickson, C., Kirsch, W., 2007. Increased production of inflammatory cytokines in mild cognitive impairment. Exp. Gerontol. 42, 233-240. https://doi.org/10.1016/j.exger.2006.09.015

Magierska, J., Magierski, R., Fendler, W., Kłoszewska, I., Sobów, T.M., 2012. Zastosowanie polskiej adaptacji montrealskiego testu do oceny funkcji poznawczych (MoCA) w przesiewowej ocenie funkcji poznawczych. Neurol. Neurochir. Pol. 46, 130-139. https://doi.org/10.5114/ninp.2012.28255

Massaccesi, L., Galliera, E., Galimberti, D., Fenoglio, C., Arcaro, M., Goi, G., Barassi, A., Corsi Romanelli, M.M., 2019. Lag-time in Alzheimer's disease patients: A potential plasmatic oxidative stress marker associated with ApoE4 isoform. Immun. Ageing 16. https://doi.org/10.1186/s12979-019-0147-x

Mazurek, J., Lurbiecki, J., 2014. Acceptance of illness scale and its clinical impact. Pol. Merkur. Lek. organ Pol. Tow. Lek. 36, 106-8.

McGeer, E.G., McGeer, P.L., 1998. The importance of inflammatory mechanisms in Alzheimer disease. Exp. Gerontol. https://doi.org/10.1016/S0531-5565(98)00013-8

Miranda, M., Morici, J.F., Zanoni, M.B., Bekinschtein, P., 2019. Brain-Derived Neurotrophic Factor: A Key Molecule for Memory in the Healthy and the Pathological Brain. Front. Cell. Neurosci. 13, 363. https://doi.org/10.3389/fncel.2019.00363

Misiak, B., Kiejna, A., 2012. Translating whole-body cryotherapy into geriatric psychiatry - A proposed strategy for the prevention of Alzheimer's disease. Med. Hypotheses 79, 56-58. https://doi.org/10.1016/j.mehy.2012.03.033

Nasreddine, Z.S., Phillips, N.A., Bedirian, V., Charbonneau, S., Whitehead, V., Collin, I., Cummings, J.L., Chertkow, H., 2005. The Montreal Cognitive Assessment, MoCA: A Brief Screening Tool For Mild Cognitive Impairment. J. Am. Geriatr. Soc. 53, 695-699. https://doi.org/10.1111/j.1532-5415.2005.53221.x

Nuzum, H., Stickel, A., Corona, M., Zeller, M., Melrose, R.J., Wilkins, S.S., 2020. Potential Benefits of Physical Activity in MCI and Dementia. Behav. Neurol. 2020, 1-10. https://doi.org/10.1155/2020/7807856

Pan, W., Banks, W.A., Fasold, M.B., Bluth, J., Kastin, A.J., 1998. Transport of brain-derived neurotrophic factor across the blood-brain barrier. Neuropharmacology 37, 1553-1561. https://doi.org/10.1016/S0028-3908(98)00141-5

Poduslo, J.F., Curran, G.L., 1996. Permeability at the blood-brain and blood-nerve barriers of the neurotrophic factors: NGF, CNTF, NT-3, BDNF. Mol. Brain Res. 36, 280-286. https://doi.org/10.1016/0169-328X(95)00250-V

Ponichtera-Kasprzykowska, M., Sobów, T., 2015. Adaptation and usage of the verbal fluency test in the world. Psychiatr. i Psychol. Klin. 14, 178-187. https://doi.org/10.15557/pipk.2014.0026

Pournot, H., Bieuzen, F., Louis, J., Fillard, J.R., Barbiche, E., Hausswirth, C., 2011. Time-Course of changes in inflammatory response after whole-body cryotherapy multi exposures following severe exercise. PLoS One 6,1-8. https://doi.org/10.1371/journal.pone.0022748

R Core Team, 2019. R: A language and environment for statistical computing.

Reginster, J.-Y., 2002. The prevalence and burden of arthritis. Rheumatology 41, 3-6. https://doi.org/10.1093/rheumatology/41.suppl_1.3

Richartz, E., Stransky, E., Batra, A., Simon, P., Lewczuk, P., Buchkremer, G., Bartels, M., Schott, K., 2005. Decline of immune responsiveness: a pathogenetic factor in Alzheimer's disease? J.

Psychiatr. Res. 39, 535-43. https://doi.org/10.1016/j.jpsychires.2004.12.005

Rivera, J., Tercero, M.J., Salas, J.S., Gimeno, J.H., Alejo, J.S., 2018. The effect of cryotherapy on 
fibromyalgia: a randomised clinical trial carried out in a cryosauna cabin. Rheumatol. Int. 38, 2243-2250. https://doi.org/10.1007/s00296-018-4176-0

Robbins, T.W., James, M., Owen, A.M., Sahakian, B.J., McInnes, L., Rabbitt, P., 1994. Cambridge Neuropsychological Test Automated Battery (CANTAB): A Factor Analytic Study of a Large Sample of Normal Elderly Volunteers. Dement. Geriatr. Cogn. Disord. 5, 266-281. https://doi.org/10.1159/000106735

Rubio-Guerra, A., Duran-Salgado, M., 2015. Recommendations for the Treatment of Hypertension in Elderly People. Cardiovasc. Hematol. Agents Med. Chem. 12, 146-151. https://doi.org/10.2174/1871525713666150310110357

Rymaszewska, J., Lion, K.M., Pawlik-Sobecka, L., Pawłowski, T., Szcześniak, D., Trypka, E., Rymaszewska, J.E., Zabłocka, A., Stanczykiewicz, B., 2020. Efficacy of the Whole-Body Cryotherapy as Add-on Therapy to Pharmacological Treatment of Depression-A Randomized Controlled Trial. Front. Psychiatry 11. https://doi.org/10.3389/fpsyt.2020.00522

Rymaszewska, J., Mazurek, J., 2012. Krioterapia ogólnoustrojowa a zaburzenia psychiczne., in: Podbielska, H., Skrzek, A. (Eds.), Zastosowanie Niskich Temperatur w Biomedycynie. Wrocław: Oficyna Wydawnicza Politechniki Wrocławskiej, Wrocław, pp. 255-263.

Rymaszewska, J., Ramsey, D., 2008. Whole body cryotherapy as a novel adjuvant therapy for depression and anxiety. Arch. Psychiatry Psychother.

Rymaszewska, J., Urbanska, K., Szcześniak, D., Pawłowski, T., Pieniawska-Śmiech, K., Kokot, I., Pawlik-Sobecka, L., Płaczkowska, S., Zabłocka, A., Stańczykiewicz, B., 2019. Whole-body cryotherapy - promising add-on treatment of depressive disorder. Psychiatr. Pol. 53, 1053-1067. https://doi.org/10.12740/PP/OnlineFirst/91298

Rymaszewska, J., Urbańska, K.M., Szcześniak, D., Stańczykiewicz, B., Trypka, E., Zabłocka, A., 2018. The improvement of memory deficits after whole-body cryotherapy - The first report. Cryo-Letters 39, 190-195.

Sadura-Sieklucka, T., Solłtysiuk, B., Karlicka, A., Sokolłowska, B., Kontny, E., KsiezopolskaOrlłowska, K., 2019. Effects of whole body cryotherapy in patients with rheumatoid arthritis considering immune parameters. Reumatologia 57, 320-325. https://doi.org/10.5114/reum.2019.90825

Saleem, M., Herrmann, N., Swardfager, W., Eisen, R., Lanctot, K.L., 2015. Inflammatory Markers in Mild Cognitive Impairment: A Meta-Analysis. J. Alzheimer's Dis. 47, 669-679. https://doi.org/10.3233/JAD-150042

Savaskan, E., Müller-Spahn, F., Olivieri, G., Bruttel, S., Otten, U., Rosenberg, C., Hulette, C., Hock, C., 2000. Alterations in Trk A, Trk B and Trk C receptor immunoreactivities in parietal cortex and cerebellum in Alzheimer's disease. Eur. Neurol. 44, 172-180. https://doi.org/10.1159/000008229

Sherman, D.S., Mauser, J., Nuno, M., Sherzai, D., 2017. The Efficacy of Cognitive Intervention in Mild Cognitive Impairment (MCI): a Meta-Analysis of Outcomes on Neuropsychological Measures. Neuropsychol. Rev. https://doi.org/10.1007/s11065-017-9363-3

Shimada, H., Makizako, H., Doi, T., Yoshida, D., Tsutsumimoto, K., Anan, Y., Uemura, K., Lee, S., Park, H., Suzuki, T., 2014. A Large, Cross-Sectional Observational Study of Serum BDNF, Cognitive Function, and Mild Cognitive Impairment in the Elderly. Front. Aging Neurosci. 6, 69. https://doi.org/10.3389/fnagi.2014.00069

Stanek, A., Cholewka, A., Gadula, J., Drzazga, Z., Sieron, A., Sieron-Stoltny, K., 2015. Can wholebody cryotherapy with subsequent kinesiotherapy procedures in closed type cryogenic chamber improve BASDAI, BASFI, and some spine mobility parameters and decrease pain intensity in patients with ankylosing spondylitis? Biomed Res. Int. 2015. https://doi.org/10.1155/2015/404259

Stanek, A., Cholewka, A., Wielkoszyński, T., Romuk, E., Sieroń, A., 2018. Decreased oxidative stress in male patients with active phase ankylosing spondylitis who underwent whole-body cryotherapy in closed cryochamber. Oxid. Med. Cell. Longev. 2018. https://doi.org/10.1155/2018/7365490

Stanek, A., Romuk, E., Wielkoszyński, T., Bartuś, S., Cieślar, G., Cholewka, A., 2019. Decreased lipid profile and oxidative stress in healthy subjects who underwent whole-body cryotherapy in closed cryochamber with subsequent kinesiotherapy. Oxid. Med. Cell. Longev. 2019. 
https://doi.org/10.1155/2019/7524878

Stanek, A., Sieroń-Stołtny, K., Romuk, E., Cholewka, A., Wielkoszyński, T., Cieślar, G., Kwiatek, S., Sieroń, A., Kawczyk-Krupka, A., 2016. Whole-Body Cryostimulation as an Effective Method of Reducing Oxidative Stress in Healthy Men. Adv. Clin. Exp. Med. 25, 1281-1291. https://doi.org/10.17219/acem/65980

Su, C., Zhao, K., Xia, H., Xu, Y., 2019. Peripheral inflammatory biomarkers in Alzheimer's disease and mild cognitive impairment: a systematic review and meta-analysis. Psychogeriatrics 19, 300-309. https://doi.org/10.1111/psyg.12403

Su, F., Bai, F., Zhang, Z., 2016. Inflammatory Cytokines and Alzheimer's Disease: A Review from the Perspective of Genetic Polymorphisms. Neurosci. Bull. 32, 469-80. https://doi.org/10.1007/s12264-016-0055-4

Szczepańska-Gieracha, J., Borsuk, P., Pawik, M., Rymaszewska, J., 2014. Mental state and quality of life after 10 session whole-body cryotherapy. Psychol. Heal. Med. https://doi.org/10.1080/13548506.2013.780130

Szcześniak, D., Rymaszewska, J., 2015. The usefulness of the SLUMS test for diagnosis of mild cognitive impairment and dementia. Psychiatr. Pol. ONLINE FIRST Nr 18. https://doi.org/10.12740/PP/OnlineFirst/43141

Szczesniak, D., Wojtynska, R., Rymaszewska, J., 2013. Test Your Memory (TYM) as a screening instrument in clinical practice - the Polish validation study. Aging Ment. Health 17, 863-868. https://doi.org/10.1080/13607863.2013.784957

Talarowska, M., Florkowski, A., Zboralski, K., Gałecki, P., 2011. Skala MoCA oraz MMSE w diagnozie łagodnych zaburzeń funkcji poznawczych. Psychiatr. i Psychoter. 7, 13-20.

Tariq, S.H., Tumosa, N., Chibnall, J.T., Perry, M.H., Morley, J.E., 2006. Comparison of the Saint Louis University Mental Status examination and the Mini-Mental State Examination for detecting dementia and mild neurocognitive disorder - A pilot study. Am. J. Geriatr. Psychiatry 14, 900-910. https://doi.org/10.1097/01.JGP.0000221510.33817.86

Tarkowski, E., Andreasen, N., Tarkowski, A., Blennow, K., 2003. Intrathecal inflammation precedes development of Alzheimer's disease. J. Neurol. Neurosurg. Psychiatry 74, 1200-5. https://doi.org/10.1136/jnnp.74.9.1200

Teixeira, A.L., Barbosa, I.G., Diniz, B.S., Kummer, A., 2010. Circulating levels of brain-derived neurotrophic factor: Correlation with mood, cognition and motor function. Biomark. Med. https://doi.org/10.2217/bmm.10.111

Tönnies, E., Trushina, E., 2017. Oxidative Stress, Synaptic Dysfunction, and Alzheimer's Disease. J. Alzheimers. Dis. 57, 1105-1121. https://doi.org/10.3233/JAD-161088

Vitenet, M., Legrand, F., Bouchet, B., Bogard, F., Taiar, R., Polidori, G., Rapin, A., Boyer, F.C., 2018. Whole body cryotherapy in fibromyalgia patients: Effects on pain and functional mobility. Ann. Phys. Rehabil. Med. 61, e1-e2. https://doi.org/10.1016/j.rehab.2018.05.004

Wang, W.Y., Tan, M.S., Yu, J.T., Tan, L., 2015. Role of pro-inflammatory cytokines released from microglia in Alzheimer's disease. Ann. Transl. Med. https://doi.org/10.3978/j.issn.23055839.2015.03.49

WHO, 2015. World Report on Ageing and Health, Antimicrobial agents and chemotherapy. https://doi.org/10.1128/AAC.03728-14

WHOQOL-BREF WHO, 1996. Introduction, Administration, Scoring and Generic Version of the Assessment-Field Trial Version. Geneva, Switzerland.

Wojtyńska, R., Szcześniak, D., 2016. DemTect ${ }^{\circledR}-$ effective to asses MCI and dementia - validation study of the Polish language version. Aging Ment. Health 20, 510-516. https://doi.org/10.1080/13607863.2015.1023763

World Health Organization, 2004. ICD-10: international statistical classification of diseases and related health problems: tenth revision., 2nd ed.

Yamauchi, T., 1986. Whole body cryo-therapy is method of extreme cold $-175^{\circ} \mathrm{C}$ treatment initially used for rheumatoid arthritis. Z. Phys. Med. Baln. Med. Klim. 15, 311.

Yesavage, J.A., Brink, T.L., Rose, T.L., Lum, O., Huang, V., Adey, M., Leirer, V.O., 1983. Development and validation of a geriatric depression screening scale: a preliminary report. J. Psychiatr. Res. 17, 37-49. https://doi.org/10.1016/0022-3956(82)90033-4 


\section{AUTHORS' STATEMENT}

Study design: BS, DS, KL, ET and JR.

Recruitment and initial screening of participants: JR, KL, BS, TP, and ET.

Blood parameters analysis: SP, IK, LP-S and AZ.

Other data analysis: KL, DS, BS, JER and JR.

Manuscript writing: JR, KL, DS, AZ, and BS.

Supervising and final version: JR, DS.

All authors have approved the final manuscript. 